\title{
Marinobacter gudaonensis sp. nov., isolated from an oil-polluted saline soil in a Chinese oilfield
}

Correspondence

Xiao-Lei Wu

xiaolei_wu@tsinghua.edu.cn
Jun Gu, ${ }^{1}$ Hua Cai, ${ }^{1}$ Su-Lin Yu, ${ }^{1}$ Ri Qu, ${ }^{1}$ Bin Yin, ${ }^{2}$ Yu-Feng Guo, ${ }^{1}$ Jin-Yi Zhao ${ }^{3}$ and Xiao-Lei $\mathrm{Wu}^{1}$

\author{
${ }^{1}$ Department of Environmental Science and Engineering, State Joint Key Laboratory of \\ Environmental Simulation and Pollution Control, Tsinghua University, Beijing 100084, China \\ ${ }^{2}$ State Key Laboratory of Soil and Sustainable Agriculture, Institute of Soil Science, Chinese \\ Academy of Sciences, Nanjing 210008, China \\ ${ }^{3}$ Daqing Oilfield Company Ltd, Daqing 163712, China
}

The genus Marinobacter was proposed by Gauthier et al. (1992) with a single species Marinobacter hydrocarbonoclasticus. The genus currently contains 14 species with validly published names (Gorshkova et al., 2003; Martín et al., 2003; Shieh et al., 2003; Yoon et al., 2003, 2004; Romanenko et al., 2005; Shivaji et al. 2005; Green et al. 2006; Kim et al. 2006; Liebgott et al. 2006). The type species, Marinobacter hydrocarbonoclasticus, is able to utilize various hydrocarbons as the sole source of carbon and energy (Gauthier et al., 1992). The second species of the genus to be recognized, Marinobacter aquaeolei, was isolated from an oil-producing well on an offshore platform in southern Vietnam (Nguyen et al., 1999). However, research by Márquez and Ventosa has suggested that M. aquaeole $i$ is a later heterotypic synonym of M. hydrocarbonoclasticus based on fatty acid composition, DNA G + C content and DNA-DNA hybridization studies (Márquez \& Ventosa, 2005). In this study, we report the

The GenBank/EMBL/DDBJ accession numbers for the 16S rRNA gene sequences of strains SL014B61A $\mathrm{A}^{\top}$ and SL014B11A are DQ414419 and DQ629025, respectively.

Electron micrographs of cells of strain SL014B61 $\mathrm{A}^{\top}$ are available as a supplementary figure in IJSEM Online. characterization of two novel strains, SL014B61A ${ }^{\mathrm{T}}$ and SL014B11A, that were isolated from an oil-polluted saline soil in a coastal oilfield in eastern China. The results indicate the two isolates represent a novel species of the genus Marinobacter.

An oil-polluted soil was sampled from a ditch containing discharged oil recovery wastewater in Gudao Oil-Product, a coastal Shengli Oilfield in Shandong Province, eastern China. The temperature of the soil was around $30^{\circ} \mathrm{C}$ all year round and the salinity of the soil was around $1 \% \mathrm{NaCl}$ $(\mathrm{w} / \mathrm{w})$. The main organic compounds in the soil were petroleum hydrocarbons. Strains SL014B61A ${ }^{\mathrm{T}}$ and SL014B11A were isolated from the soil by a 10-fold dilution plating technique on inorganic salts agar containing $(\mathrm{w} / \mathrm{v})$ $0.5 \% \mathrm{NaCl}, 0.1 \% \mathrm{NH}_{4} \mathrm{H}_{2} \mathrm{PO}_{4}, 0.1 \%\left(\mathrm{NH}_{4}\right)_{2} \mathrm{SO}_{4}, 0.02 \%$ $\mathrm{MgSO}_{4} .7 \mathrm{H}_{2} \mathrm{O}, 0.3 \% \mathrm{KNO}_{3}, 0.1 \% \mathrm{~K}_{2} \mathrm{HPO}_{4}$ and distilled oil recovery wastewater instead of pure water. The isolates were purified by restreaking on plates of inorganic salts agar incubated for $3-5$ days at $30^{\circ} \mathrm{C}$.

After the strains had grown to late exponential phase on marine agar 2216 (MA), cell morphology and flagellum type were examined using transmission and scanning electron 
microscopy. Carbon source assimilation was tested using the mineral medium solution of Shivaji et al. (2005). Each carbon source was added at a concentration of $0.2 \%(\mathrm{w} / \mathrm{v})$ after the mineral base solution had been autoclaved. Growth was examined after incubation at $30^{\circ} \mathrm{C}$ for $1,7,10$ and 14 days. Hydrolysis of starch, gelatin and Tween 80 was assessed as described by Smibert \& Krieg (1994). Nitrate and nitrite reduction were assessed as described by Lanyi (1987). Optimum $\mathrm{pH}$ and temperature for growth were determined using marine broth 2216. The requirement for and tolerance of various $\mathrm{NaCl}$ concentrations were determined in a medium containing $\left(\mathrm{l}^{-1}\right): 1.0 \mathrm{~g} \mathrm{MgCl}_{2} .6 \mathrm{H}_{2} \mathrm{O}, 5.0 \mathrm{~g} \mathrm{MgSO}_{4} .7 \mathrm{H}_{2} \mathrm{O}$, $0.7 \mathrm{~g} \mathrm{KCl}, 0.15 \mathrm{~g} \mathrm{CaCl}_{2} .2 \mathrm{H}_{2} \mathrm{O}, 0.5 \mathrm{~g} \mathrm{NH}_{4} \mathrm{Cl}, 0.1 \mathrm{~g} \mathrm{KBr}, 0.27 \mathrm{~g}$ $\mathrm{KH}_{2} \mathrm{PO}_{4}, 0.04 \mathrm{~g} \mathrm{SrCl}_{2} .6 \mathrm{H}_{2} \mathrm{O}, 0.025 \mathrm{~g} \mathrm{H}_{3} \mathrm{BO}_{3}, 5.0$ g peptone and $1.0 \mathrm{~g}$ yeast extract $(\mathrm{pH} 8.0)$ with various $\mathrm{NaCl}$ concentrations $(0,0.5,1,3,5,10,15,18,20$ and $25 \%)$. Sensitivity to various antibiotics (kanamycin, tetracycline, chloramphenicol, ampicillin, streptomycin, erythromycin and gentamicin) was tested by using the method described by Cho \& Giovannoni (2003).

Cells of strain SL014B61A ${ }^{\mathrm{T}}$, Marinobacter bryozoorum DSM $15401^{\mathrm{T}}$ and Marinobacter lipolyticus $\mathrm{SM} 19^{\mathrm{T}}$ were grown on $\mathrm{MA}$ at $28^{\circ} \mathrm{C}$ for 3 days for cellular fatty acid analyses. Cellular fatty acid methyl esters were prepared and analysed using GC according to the instructions of the Microbial Identification System (MIDI). Fatty acid profiles were analysed by the Sherlock system (Microbial ID). Lipoquinones were extracted from lyophilized cells with chloroform/methanol $(2: 1, \mathrm{v} / \mathrm{v})$ as described by Tindall (1990). Respiratory lipoquinones were analysed using reversedphase HPLC (Shim-pack, VP-ODS, Shimadzu). Genomic DNA was extracted and purified by the method of Marmur (1961) and DNA purity was assessed by the $A_{280} / A_{260}$ and $A_{230} / A_{260}$ ratios (Johnson, 1994). The DNA G + C content was determined by thermal denaturation (Marmur \& Doty, 1962) using DNA from Escherichia coli K-12 as a control. The 16S rRNA gene was amplified as described previously (Rainey et al., 1996), except that the following pair of bacterial universal primers was used: 8f, 5' -AGAGTTTGATCCTGGCTCAG-3' and 1492r, 5'-GGTTACCTTGTTACGACTT-3'. 16S rRNA gene sequence alignments were performed with the CLUSTAL_X program (version 1.64b; Thompson et al., 1997). A phylogenetic tree was constructed using the neighbour-joining method (Saitou \& Nei, 1987) and evaluated by bootstrap analysis based on 1000 resampling replicates with the SEQBOOT, DNADIST, NEIGHBOR and CONSENSE programs of the PHYLIP software package version 3.6 (Felsenstein, 2004). DNA-DNA hybridization was performed in triplicate by the thermal denaturation and renaturation method of Huß et al. (1983), modified from that of De Ley et al. (1970). The temperature of renaturation was $76.5^{\circ} \mathrm{C}$ in $2 \times$ SSC buffer $(0.15 \mathrm{M} \mathrm{NaCl}$ buffered with $0.015 \mathrm{M}$ trisodium citrate, $\mathrm{pH}$ 7.0).

The two novel isolates were Gram-negative, rod-shaped and motile with a polar flagellum (see Supplementary Fig. S1a, b in IJSEM Online). The small creamy colonies (about
1-2 $\mathrm{mm}$ ) were produced on MA after incubation at $30^{\circ} \mathrm{C}$ for 3-5 days. Colonies were smooth, uniformly circular, flat and a little transparent. The $\mathrm{pH}$ range and $\mathrm{NaCl}$ concentrations for growth were $\mathrm{pH}$ 6.0-9.5 (optimum $\mathrm{pH}, 7.5-8.0$ ) and $0 \%-15 \% \mathrm{NaCl}(\mathrm{w} / \mathrm{v})$ (optimum $\mathrm{NaCl} 2.0-3.0 \%$ ). Growth was observed at temperatures of $10-45^{\circ} \mathrm{C}$, but not at $4{ }^{\circ} \mathrm{C}$ or $50^{\circ} \mathrm{C}$. The novel isolates gave a positive reaction in tests for catalase and oxidase and reduced nitrate to nitrite. Nitrite was not reduced to $\mathrm{N}_{2}$. Starch and Tween 80 were hydrolysed, but no hydrolysis of urea or gelatin was detected. Both strains were susceptible to kanamycin, tetracycline, ampicillin, chloramphenicol, streptomycin, erythromycin and gentamicin. The other main characteristics that differentiate the novel strains from the type strains of species of the genus Marinobacter are listed in Table 1.

Almost complete 16S rRNA gene sequences were determined for strains SL014B61A ${ }^{\mathrm{T}}$ and SL014B11A. Analysis of the $16 \mathrm{~S}$ rRNA gene sequences revealed that strain SL014B61A ${ }^{\mathrm{T}}$ was a member of the class Gammaproteobacteria and had a close phylogenetic relationship with species of the genus Marinobacter; 16S rRNA gene sequence similarity ranged from 94.2 to $97.9 \%$ (Fig. 1). The $16 \mathrm{~S}$ rRNA gene sequence of strain SL014B61A ${ }^{\mathrm{T}}$ had $100 \%$ similarity to that of strain SL014B11A. The novel strains were most closely related to M. bryozoorum DSM $15401^{\mathrm{T}}$ $(97.9 \%)$ and $M$. lipolyticus $\mathrm{SM}_{1}{ }^{\mathrm{T}}(97.8 \%)$. Lower similarity values were observed with other Marinobacter species, such as M. hydrocarbonoclasticus ATCC $49840^{\mathrm{T}}$ $(94.9 \%)$ and Marinobacter litoralis SW $-45^{\mathrm{T}}(94.2 \%)$.

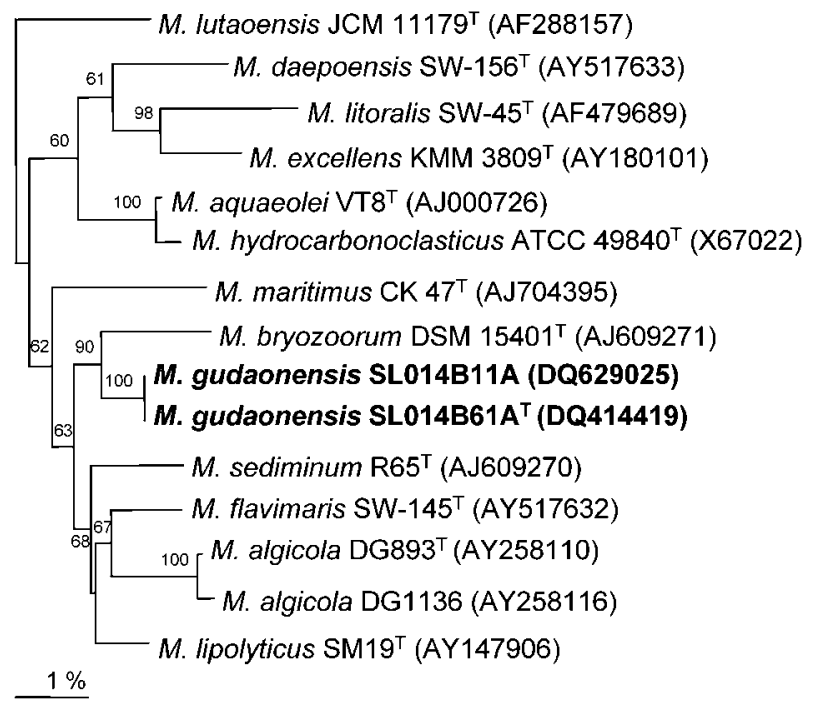

Fig. 1. Phylogenetic position of Marinobacter gudaonensis sp. nov. and other Marinobacter species according to 16S rRNA gene sequence analysis. The topology shown was obtained by using neighbour-joining methods. Bootstrap values (expressed as percentages of 1000 replications) greater than $50 \%$ are shown at branch points. Bar, $1 \%$ sequence divergence. 
Table 1. Characteristics that differentiate Marinobacter gudaonensis sp. nov. from related species of the genus Marinobacter

Strains: 1, M. gudaonensis SL014B61A ${ }^{\mathrm{T}}$; 2, M. bryozoorum DSM $15401^{\mathrm{T}}$; 3, M. lipolyticus SM19 ${ }^{\mathrm{T}}$. Data for carbon utilization are from the present study and other data were obtained from Martín et al. (2003) and Yoon et al. (2004). All strains are positive for motility, catalase and oxidase activities and utilization of acetate, pyruvate and glycerol. All strains are negative for hydrolysis of gelatin and urea and do not utilize L-arginine, D-melezitose, D-erythritose, formate, L-lysine, malonic acid, myo-inositol, D-melibiose, $\alpha$-lactose, D-ribose, glycine, lactic acid, L-glutamic acid or - , Negative; + , positive; $(+)$, weakly positive.

\begin{tabular}{|c|c|c|c|}
\hline Characteristic & 1 & 2 & 3 \\
\hline Cell size $(\mu \mathrm{m})$ & $0.3-0.5 \times 1.2-1.8$ & $0.4-0.5 \times 1.0-1.3$ & $0.3-0.5 \times 2.5-3.5$ \\
\hline Min. growth temperature $\left({ }^{\circ} \mathrm{C}\right)$ & 10 & 7 & 15 \\
\hline Max. growth temperature $\left({ }^{\circ} \mathrm{C}\right)$ & 45 & 42 & 40 \\
\hline $\mathrm{NaCl}$ range for growth $(\%)$ & $0-15$ & $1-18$ & $1-15$ \\
\hline \multicolumn{4}{|l|}{ Utilization of: } \\
\hline L-Alanine & + & - & - \\
\hline D-Arabinose & - & - & + \\
\hline D-Cellobiose & $(+)$ & - & + \\
\hline Citrate & + & - & + \\
\hline Dextrin & + & - & + \\
\hline Ethanol & + & $(+)$ & $(+)$ \\
\hline D-Fructose & + & - & + \\
\hline D-Galactose & $(+)$ & $(+)$ & - \\
\hline Gluconate & - & - & + \\
\hline D-Glucose & + & - & + \\
\hline L-Isoleucine & + & - & + \\
\hline D-Maltose & + & - & + \\
\hline D-Mannitol & - & - & + \\
\hline D-Mannose & - & + & $(+)$ \\
\hline L-Proline & + & - & + \\
\hline Propionate & + & - & + \\
\hline D-Raffinose & - & - & - \\
\hline L-Rhamnose & - & + & + \\
\hline D-Sorbitol & + & - & + \\
\hline L-Sorbose & - & - & - \\
\hline Succinate & + & - & + \\
\hline Sucrose & + & + & - \\
\hline D-Trehalose & + & $(+)$ & $(+)$ \\
\hline D-Xylose & + & + & $(+)$ \\
\hline DNA G $+\mathrm{C}$ content $(\mathrm{mol} \%)$ & 57.9 & 59.6 & 57.0 \\
\hline
\end{tabular}

Whole-genome DNA-DNA hybridization studies were performed with strains SL014B61A ${ }^{\mathrm{T}}$ and SL014B11A, $M$. bryozoorum DSM $15401^{\mathrm{T}}$ and M. lipolyticus SM19 ${ }^{\mathrm{T}}$. DNADNA relatedness values (based on three independent determinations) for the strain SL014B61A ${ }^{\mathrm{T}}$ with strain SL014B11A, M. bryozoorum and M. lipolyticus were $95.5 \%$ $(\mathrm{SD}=4.7 \%), 35.5 \%(\mathrm{SD}=5.8 \%)$ and $33.8 \%(\mathrm{SD}=5.5 \%)$, respectively.

The results of the cellular fatty acid content analysis are given in Table 2. Fatty acids $\mathrm{C} 12: 0$ 3-OH, C16:0, $\mathrm{C} 16: 1 \omega 9 c$ and $\mathrm{C} 18: 1 \omega 9 c$ have been reported to be predominant in other known Marinobacter species (Spröer et al., 1998; Nguyen et al., 1999; Martín et al., 2003; Yoon et al., 2003, 2004). The predominant cellular fatty acids of strain SL014B61A ${ }^{\mathrm{T}}$ were C16:0 $(21.2 \%)$, C18:1 $109 c$ $(20.3 \%), \mathrm{C} 18: 3 \omega 6 c(6,9,12)(8.5 \%), \mathrm{C} 16: 1 \omega 7 c(7.3 \%)$ and $\mathrm{C} 16: 1 \omega 9 c(6.4 \%)$. This differed from those of the reference species $M$. bryozoorum DSM $15401^{\mathrm{T}}$, but was similar to those of $M$. lipolyticus $\mathrm{SM} 19^{\mathrm{T}}$. The $\mathrm{G}+\mathrm{C}$ content of strain SL014B61A ${ }^{\mathrm{T}}$ was $57.9 \mathrm{~mol} \%\left(T_{\mathrm{m}}\right)$.

On the basis of physiological and molecular properties, it is proposed that strains SL014B61A ${ }^{\mathrm{T}}$ and SL014B11A represent a novel species of the genus Marinobacter, for which we propose the name Marinobacter gudaonensis sp. nov. 
Table 2. Cellular fatty acid content of strain SL014B61 $A^{\top}$ and related species of the genus Marinobacter grown on MA

Species: 1, M. gudaonensis SL014B61A ${ }^{\mathrm{T}}$; 2, M. bryozoorum DSM $15401^{\mathrm{T}}$; 3, M. lipolyticus $\mathrm{SM} 19^{\mathrm{T}}$. Values are percentages of total fatty acids; values $<1 \%$ are not shown.

\begin{tabular}{|lccc|}
\hline Fatty acid & $\mathbf{1}$ & $\mathbf{2}$ & $\mathbf{3}$ \\
\hline $\mathrm{C} 12: 0$ & 2.8 & 4.3 & 3.7 \\
$\mathrm{C} 12: 03-\mathrm{OH}$ & 3.4 & 8.3 & 5.8 \\
$\mathrm{C} 14: 0$ & 1.3 & 0.8 & 1.0 \\
$\mathrm{C} 16: 0 \mathrm{~N}$ alcohol & 7.1 & 0 & 5.6 \\
$\mathrm{C} 16: 0$ & 21.2 & 20.0 & 23.0 \\
$\mathrm{C} 16: 1 \omega 7 c$ & 7.3 & 0.5 & 6.3 \\
$\mathrm{C} 16: 1 \omega 9 c$ & 6.4 & 2.6 & 8.5 \\
$10-$ Methyl C16:0 & 2.5 & 0 & 1.1 \\
$\mathrm{C} 17: 0$ & 0.9 & 2.9 & 0.7 \\
$\mathrm{C} 17: 1 \omega 8 c$ & 1.1 & 1.1 & 1.2 \\
$10-\mathrm{Methyl} \mathrm{C17:0}$ & 4.5 & 0 & 3.0 \\
$\mathrm{C} 18: 0$ & 5.6 & 4.9 & 2.9 \\
$\mathrm{C} 18: 1 \omega 7 c$ & 5.4 & 0.7 & 4.9 \\
$\mathrm{C} 18: 1 \omega 9 c$ & 20.3 & 45.8 & 27.4 \\
$\mathrm{C} 18: 3 \omega 6 c(6,9,12)$ & 8.5 & 0 & 4.1 \\
$\mathrm{C} 19: 0 \omega 10 c$ cyclo & 0 & 7.0 & 0 \\
\hline
\end{tabular}

\section{Description of Marinobacter gudaonensis sp. nov.}

Marinobacter gudaonensis (gu.dao.nen'sis. N.L. masc. adj. gudaonensis pertaining to Gudao of the Shengli Oilfield, P. R. China, from where the type strain was first isolated.)

Cells are Gram-negative, rod-shaped $(0.3-0.5 \times 1.2-1.8 \mu \mathrm{m})$ and motile with a polar flagellum on semi-solid medium. Growth occurs in $0-15 \% \mathrm{NaCl}$ at temperatures of between 10 and $45^{\circ} \mathrm{C}$. Colonies on MA are smooth, uniformly circular, flat and a little transparent after 3-5 days. Positive results in tests for catalase, oxidase and nitrate-reducing activities and for the hydrolysis of starch and Tween 80 . Negative results in tests for gelatin hydrolysis and urease and nitrite-reducing activities. The following substrates are utilized as a sole carbon source for growth: D-maltose, L-proline, dextrin, D-glucose, citrate, D-xylose, L-alanine, propionate, ethanol, D-fructose, pyruvate, D-trehalose, sucrose, D-sorbitol, acetate, succinate and D-galactose. Sensitive to kanamycin $(10 \mu \mathrm{g})$, tetracycline $(5 \mu \mathrm{g})$, chloramphenicol $(10 \mu \mathrm{g})$, ampicillin $(10 \mu \mathrm{g})$, streptomycin $(10 \mu \mathrm{g})$, erythromycin $(10 \mu \mathrm{g})$ and gentamicin $(10 \mu \mathrm{g})$. Q9 is a main respiratory quinone and C16:0 (21.2\%), C18 : $1 \omega 9 c(20.3 \%), \mathrm{C} 18: 3 \omega 6 c(6,9,12)(8.5 \%), \mathrm{C} 16: 1 \omega 7 c$ $(7.3 \%)$ and $\mathrm{C} 16: 1 \omega 9 c(6.4 \%)$ are the predominant fatty acids. The $\mathrm{G}+\mathrm{C}$ content of the DNA is $57.9 \mathrm{~mol} \%\left(T_{\mathrm{m}}\right)$.

The type strain, SL014B61A ${ }^{\mathrm{T}} \quad\left(=\mathrm{DSM} \quad 18066^{\mathrm{T}}=\mathrm{LMG}\right.$ $23509^{\mathrm{T}}=$ CGMCC $1.6294^{\mathrm{T}}$ ), was isolated from an oilpolluted saline soil in Gudao in the coastal Shengli Oilfield, eastern China. Strain SL014B11A is a reference strain.

\section{Acknowledgements}

The type strains of Marinobacter excellens (KMM $3809^{\mathrm{T}}$ ) and $M$. lipolyticus $\left(\mathrm{SM} 19^{\mathrm{T}}\right)$ were generous gifts from Dr Ivanova and $\mathrm{Dr}$ A. Ventosa. The authors would like to thank G.-F. Zhao, Z.-Y. Lou and B. Guo for their valuable help and discussion. This study was supported by the National Natural Science Foundation of China (30300008, 30570033) and the National Basic Research Program of China (2005CB221308)

\section{References}

Cho, J.-C. \& Giovannoni, S. J. (2003). Parvularcula bermudensis gen. nov., sp. nov., a marine bacterium that forms a deep branch in the $\alpha$-Proteobacteria. Int J Syst Evol Microbiol 53, 1031-1036.

De Ley, J., Cattoir, H. \& Reynaerts, A. (1970). The quantitative measurement of DNA hybridization from renaturation rates. Eur $J$ Biochem 12, 133-142.

Felsenstein, J. (2004). PHYLIP (phylogeny inference package), version 3.6. Distributed by the author. Department of Genome Sciences, University of Washington, Seattle, USA.

Gauthier, M. J., Lafay, B., Christen, R., Fernandez, L., Acquaviva, M., Bonin, P. \& Bertrand, J.-C. (1992). Marinobacter hydrocarbonoclasticus gen. nov., sp. nov., a new, extremely halotolerant, hydrocarbon degrading marine bacterium. Int J Syst Bacteriol 42, 568-576.

Gorshkova, N. M., Ivanova, E. P., Sergeev, A. F., Zhukova, N. V., Alexeeva, Y., Wright, J. P., Nicolau, D. V., Mikhailov, V. V. \& Christen, R. (2003). Marinobacter excellens sp. nov., isolated from sediments of the Sea of Japan. Int J Syst Evol Microbiol 53, 2073-2078.

Green, D. H., Bowman, J. P., Smith, E. A., Gutierrez, T. \& Bolch, C. J. S. (2006). Marinobacter algicola sp. nov., isolated from laboratory cultures of paralytic shellfish toxin-producing dinoflagellates. Int J Syst Evol Microbiol 56, 523-527.

Huß, V. A. R., Festl, H. \& Schleifer, K. H. (1983). Studies on the spectrophotometric determination of DNA hybridization from renaturation rates. Syst Appl Microbiol 4, 184-192.

Johnson, J. L. (1994). Similarity analysis of DNAs. In Methods for General and Molecular Bacteriology, pp. 655-682. Edited by P. Gerhardt, R. G. E. Murray, W. A. Wood \& N. R. Krieg. Washington, DC: American Society for Microbiology.

Kim, B.-Y., Weon, H.-Y., Yoo, S.-H., Kim, J.-S., Kwon, S. W., Stackebrandt, E. \& Go, S.-J. (2006). Marinobacter koreensis sp. nov., isolated from sea sand in Korea. Int J Syst Evol Microbiol 56, 2653-2656.

Lanyi, B. (1987). Classical and rapid identification methods for medically important bacteria. Methods Microbiol 19, 1-67.

Liebgott, P.-P., Casalot, L., Paillard, S., Lorquin, J. \& Labat, M. (2006). Marinobacter vinifirmus sp. nov., a moderately halophilic bacterium isolated from a wine-barrel-decalcification wastewater. Int J Syst Evol Microbiol 56, 2511-2516.

Marmur, J. (1961). A procedure for the isolation of deoxyribonucleic acid from microorganisms. J Mol Biol 3, 208-218.

Marmur, J. \& Doty, P. (1962). Determination of the base composition of deoxyribonucleic acid from its thermal denaturation temperature. J Mol Biol 5, 109-118.

Márquez, M. C. \& Ventosa, A. (2005). Marinobacter hydrocarbonoclasticus Gauthier et al. 1992 and Marinobacter aquaeolei Nguyen et al. 1999 are heterotypic synonyms. Int J Syst Evol Microbiol 55, 1349-1351.

Martín, S., Márquez, M. C., Sánchez-Porro, C., Mellado, E., Arahal, D. R. \& Ventosa, A. (2003). Marinobacter lipolyticus sp. nov., a novel moderate halophile with lipolytic activity. Int J Syst Evol Microbiol 53, 1383-1387. 
Nguyen, B. H., Denner, E. B. M., Ha, D. T. C., Wanner, G. \& Stan-Lotter, H. (1999). Marinobacter aquaeolei sp. nov., a halophilic bacterium isolated from a Vietnamese oil-producing well. Int J Syst Bacteriol 49, 367-375.

Rainey, F. A., Ward-Rainey, N., Kroppenstedt, R. M. \& Stackebrandt, E. (1996). The genus Nocardiopsis represents a phylogenetically coherent taxon and a distinct actinomycete lineage: proposal of Nocardiopsaceae fam. nov. Int J Syst Bacteriol 46, 1088-1092.

Romanenko, L. A., Schumann, P., Rohde, M., Zhukova, N. V., Mikhailov, V. V. \& Stackebrandt, E. (2005). Marinobacter bryozoorum sp. nov. and Marinobacter sediminum sp. nov., novel bacteria from the marine environment. Int J Syst Evol Microbiol 55, 143-148.

Saitou, N. \& Nei, M. (1987). The neighbor-joining method: a new method for reconstructing phylogenetic trees. Mol Biol Evol 4, 406-425.

Shieh, W. Y., Jean, W. D., Lin, Y. T. \& Tseng, M. (2003). Marinobacter lutaoensis sp. nov., a thermotolerant marine bacterium isolated from a coastal hot spring in Lutao, Taiwan. Can J Microbiol 49, 244-252.

Shivaji, S., Gupta, P., Chaturvedi, P., Suresh, K. \& Delille, D. (2005). Marinobacter maritimus sp. nov., a psychrotolerant strain isolated from sea water off the subantarctic Kerguelen islands. Int J Syst Evol Microbiol 55, 1453-1456.
Smibert, R. M. \& Krieg, N. R. (1994). Phenotypic characterization. In Methods for General and Molecular Bacteriology, pp. 607-654. Edited by P. Gerhardt, R. G. E. Murray, W. A. Wood \& N. R. Kreig. Washington, DC: American Society for Microbiology.

Spröer, C., Lang, E., Hobeck, P., Burghardt, J., Stackebrandt, E. \& Tindall, B. J. (1998). Transfer of Pseudomonas nautica to Marinobacter hydrocarbonoclasticus. Int J Syst Bacteriol 48, 1445-1448.

Thompson, J. D., Gibson, T. J., Plewniak, F., Jeanmougin, F. \& Higgins, D. G. (1997). The CLUSTAL_X windows interface: flexible strategies for multiple sequence alignment aided by quality analysis tools. Nucleic Acids Res 25, 4876-4882.

Tindall, B. J. (1990). Lipid composition of Halobacterium lacusprofundi. FEMS Microbiol Lett 66, 199-202.

Yoon, J.-H., Shin, D.-Y., Kim, I.-G., Kang, K. H. \& Park, Y.-H. (2003). Marinobacter litoralis sp. nov., a moderately halophilic bacterium isolated from sea water from the East Sea in Korea. Int J Syst Evol Microbiol 53, 563-568.

Yoon, J.-H., Yeo, S. H., Kim, I.-G. \& Oh, T. K. (2004). Marinobacter flavimaris sp. nov. and Marinobacter daepoensis sp. nov., slightly halophilic organisms isolated from sea water of the Yellow Sea in Korea. Int J Syst Evol Microbiol 54, 1799-1803. 